\title{
THE ECONOMIC EFFECTS OF FARM VEHICLE-RELATED TRAFFIC ACCIDENTS - A COMPARATIVE ANALYSIS OF WESTERN AND NORTHERN SERBIAN MUNICIPALITIES
}

\author{
Dragan Obradović ${ }^{1}$, Duško Ranisavljević ${ }^{2}$, Zdravko Petrović ${ }^{3}$ \\ *Corresponding author E-mail: dr.gaga.obrad@gmail.com
}

\begin{abstract}
A R T I C LE I N F O
Review Article

Received: 06 August2018

Accepted: 06 November 2018

doi:10.5937/ekoPolj1804483O

UDC 338.054.23:[631.372+614.86(497.11)
\end{abstract}

Keywords:

traffic accidents, farm vehicles, tractors, economic damage

JEL: K14, K32

\begin{abstract}
A B S T R A C T
There are numerous and diverse Serbian road users or traffic participants on a daily basis. Farm vehicles are also considered participants. In fact, from all the farm vehicles engaged in traffic, it is tractors that are involved the most in traffic accidents. In this paper, we will present valid data on tractor-related traffic accidents during the 20122016 period, with a focus on areas under the jurisdiction of two police administrations from different parts of Serbia - Valjevo and Subotica. By analyzing data on farmsteads and comparing traffic accidents in these areas, we pointed out the multiple negative economic effects and possible measures for their mitigating, as well as the differences between the regions of western and northern Serbia. This data, indicates that there should be more focus on the consequences resulting from these incidents as they indicate the most diverse segments of damage in the area of agriculture.
\end{abstract}

(C) 2018 EA. All rights reserved.

\section{Introduction}

Criminal offenses against public traffic safety, has now become a world trend and a big problem in the $20^{\text {th }}$ century. The United Nations (hereinafter: UN) and the World Health Organization (hereinafter: WHO) estimate that the importance of traffic accidents is rising and that by 2020, it will rise to third place as a cause of death on a global level. Also, WHO data shows that traffic accidents were the second leading cause of death among persons aged 15 to 29 in 2001, and the first leading cause of death among men of the same age. Youth participation in the total population in OECD countries was only

1 Dragan Obradović, PhD, judge, Higher Court in Valjevo, Karadjordjeva 48, Assistant Professor, Singidunum University, Faculty of Health, Legal and Business Studies, Valjevo, Železnička 5, Republic of Serbia, Phone:+381 6462317 01,dr.gaga.obrad@gmail.com

2 Duško Ranisavljević, PhD, Assistant Professor, Singidunum University, Faculty of Health, Legal and Business Studies, Valjevo, Železnička 5, Republic of Serbia, Phone:+381 6588 33 294, dranisavljevic@singidunum.ac.rs

3 Zdravko Petrović, PhD, Full professor, Faculty of Law, Bulevar umetnosti Street no. 29, 11070 Novi Beograd, Republic of Serbia, Phone:+381 63575 880, petroviczdravko@sbb.rs 
$10 \%$ in 2004, while the percentage of young drivers in the total number of those killed in road crashes amounted to as much as $27 \%(\mathrm{OECD}, 2006)$. At the same time, traffic accidents are the leading cause of death among those between 15 and 44 (WHO, 2004). This particularly applies to traffic road accidents because they have the greatest and most severe consequences in terms of the number of casualties and the damage caused. These are the consequences that directly affect participants in traffic accidents, but also every state, due to a reduction of the gross domestic product. One of the important branches that affect the GDP in every country is agriculture. Traffic participants driving farm vehicles are on the road daily, and therefore they also take part in traffic road accidents. Drivers belong to all age categories, especially tractor drivers, and not only in Serbia but everywhere.

There are numerous studies in the world that aim to help increase road traffic safety and reduce the amount of damage resulting from these accidents whereupon farm vehicles, above all tractors, are involved. Some authors support the use of simulations to assess the ability of minors to handle tractors safely (Marlenga et al., 2017). Other authors, using the SafeDriving application, demonstrate the way a mobile electronic device can be used to monitor tractor stability (Liu et al., 2013). On the other hand, some authors are engaged in developing a computer program for the design of ROPS - the rollover protection structure (Ayers et al., 2017). Other domestic authors have also pointed out the dangers of farm vehicles, primarily tractors, as road traffic participants, noting that due to the fact that these are slow moving vehicles, there are often long lines of vehicles on the roads, causing hazardous situations due to the perilous overtaking of tractors. Furthermore, they gave some suggestions on how to improve general road safety in such situations (Marković et al., 2013). Important is their proposal that the Road Traffic Safety Law should also regulate the installing of cabs or tractor frames, which would reduce the consequences of overturned tractors. A technical inspection should regularly check the condition of the cabins or frames so that they can effectively protect drivers or passengers from injury. These proposals are in line with the aforementioned international experiences. The danger of driving a tractor at night is also recognized in research papers by domestic authors (Pešić et al., 2010), which contain the following statement, among others: "It is a very frequent occurrence that tractor trailers are loaded with a certain cargo that covers the light signaling devices at the back of the vehicle. This would be the equivalent of having no rear light signaling devices."

Bearing in mind the mentioned international data and the domestic research papers, we tried to present in a limited manner the relevant data pertaining to road traffic accident victims driving farm vehicles on the roads in Serbia in the period from 2012 to 2016 , in which tractors were involved. The 5 year period is a sufficiently lengthy one, and relevant data published by official authorities was used. We paid special attention to areas that are under the jurisdiction of two police administrations from different parts of Serbia - Valjevo and Subotica. The Police Administration (hereinafter: PA) in Valjevo, covers the area of six municipalities within the territory of the Kolubara Administrative District - Valjevo, Ub, Lajkovac, Ljig, Mionica and Osečina, including to some extent 
the Ibar Highway - one of the most important thoroughfares roads in the country. The area of PA Subotica includes, also six municipalities - Subotica, Ada, Bačka Topola, Mali Iđoš, Kanjiža, and Senta.The same data was also analyzed compared with the official data of the PA of Valjevo and the PA of Subotica for criminal offenses against public traffic safety in the same 5 year period. The area of PA Subotica involves a border area located at the entrance of the most important international thoroughfares in Serbia, where there is a high frequency of passenger and freight traffic. The area under the jurisdiction of the PA of Subotica was of interest to us as it involves a territory with the same number of inhabitants as in the PA of Valjevo.

Based on the appropriate economic indicators, we tried to present data regarding the damage (material and non-material) resulting from road traffic accidents in these two areas. Each region has six municipalities, so data was analyzed both for municipalities individually and for the regions. Negative economic effects are indicated in the opportunity costs, which are manifested due to the injury or death of a farmstead member, but also other costs caused by the death of a farmstead member. The aim of the research and analysis is to point out the complexity of the economic damage arising from traffic accidents and the consequences for farmstead members.

This paper presents and tests certain hypotheses, pointed out the methodology of the research and the importance of the analysis for improving the road traffic safety in the mountain and plain regions, as well as the possible measures for mitigating the negative effects. In the end, we presented some conclusions that confirmed our hypotheses which are the basis of this paper. It is not known to us whether any other Serbian authors have dealt with a comprehensive analysis of the negative economic effects arising from the aforementioned types of traffic accidents that occur on the roads in the Republic of Serbia.

\section{Literature review}

Particularly worrying are the data on the harmful consequences of traffic accidents in view of global traffic statistics. When these data are taken into account, and the reality in the Republic of Serbia tallies with these catastrophic figures, the data on the level of economic and social damage gain even more significance. According to 2007 data from in Europe, there were 1,300,000 road traffic accidents that killed more than 127,000 people while more than 2.4 million were injured or otherwise disabled, and the damage amounted to between 1.5 and $2.5 \%$ of the GDP. Of the total number of all casualties, $20 \%$ were young people, aged 18 to 25 . The direct and indirect costs of the casualties of road traffic accidents are estimated at approximately $2 \%$ of the European GDP (European Charter, AMS, 2009).

On the other hand, the development of transport infrastructure, and technical and technological progress contributes to increasingly intensive traffic. Consequently, the factors contributing to the occurrence of road traffic accidents and, consequently, traffic offenses, are also escalating, which implies the total offenses against road traffic safety within a given time and space. Road traffic accidents and the traffic-related death rate 
are a major problem for modern civilization. To reduce the number of casualties in road traffic accidents is therefore a worldwide requirement.There is a special focus on the issue of traffic-related victims, especially in the European Union and the UN (UN, EU 2010). Thus, on March 2, 2010, the UN General Assembly unanimously adopted Resolution No. 64/255 on implementing road safety activities and proclaimed the period 2011-2020 as the Decade of Action for Road Safety targeted at road traffic casualty reduction on roads throughout the world by increasing activities on the national, regional and world level (UN, 2010), with May 11, 2011 being designated as the beginning of this action. The Decade of Traffic Safety Plan of Action is a framework for action by all member states and communities to implement road safety management around the world. This plan was also implemented by the Republic of Serbia.

Traffic participation on public roads has become an integral and inevitable part of daily life. According to some estimates, a typical driver today spends at least two hours a day in the car, which makes up almost a third of a six-hour work day (Günther, 2005). The issue of road traffic safety is not a police problem, nor is it simply a traffic issue. Traffic injuries are, above all, a public health issue, and then a social, ethical, human and economic community issue. Namely, a great number of people die and are injured in traffic, with some remaining life-long invalids. This significantly impairs human health, destroys families, as well as creating social and humanitarian problems. Finally, the huge socio-economic cost of traffic accidents is compensated by the state economy, which hinders the economic development of the community at large.

The work environment has a greater effect on the accident rate when farm vehicles, or tractors, are involved (Blower et al., 1993). Thus, in the United States, agriculture is the most risky branch of industry for the young workforce (Centers for Disease Control, 2003). Thus, it is a known fact that overturning tractors is the leading cause of death in American agriculture (NORAAgFF Sector Council, 2008). There is no general agreement on minimum age or developmental stages when it is safe for minors to drive tractors (Lee \& Marlenga, 1999), and therefore, minors driving tractors prior to gaining the required developmental and cognitive abilities are at a greater risk of trauma (Schwebel \& Pickett, 2012). In the member states of the European Union (EU) overturning tractors are the leading cause of death in the agricultural sector. According to a survey conducted by the European Commission of the EU Member States, $40 \%$ of serious injuries and fatal accidents occur when a tractor overturns when a rollover protection structure (ROPS) was not applied in a protecting position (Hoy, 2009). In the region of Murcia, Spain, during the 2005-2012 period, there were 44 accidents with tractors, and in three out of four incidents, ROPS was in a horizontal position (unsafe) (Martin-Gorriz et al., 2012).

In order to present this paper, it is necessary to briefly indicate the criminal offenses against the safety of public traffic envisaged in the current Criminal Code of the Republic of Serbia (hereinafter: CC). The code which is valid from 1 January 2006, regulates the matter of criminal legislation, while the criminal offenses against the safety of public traffic are set out in Chapter 26. This group includes 9 criminal offenses. Significant for this paper are: endangering public transport (Art. 289), failure to provide assistance to 
a person injured in a traffic accident (Art. 296) and serious offenses against the security of public traffic (Art. 297) in which a driver driving a tractor may appear as an offender. These are the most common criminal offenses that appear in court practice.

Although motor vehicles, after pedestrians, are the most frequent traffic participants, the numerous farming vehicles are on the roads every day. The most common farm vehicles on the roads of Serbia are tractors. Official data is also indicative of the dangers of farm vehicles, particularly tractors. Thus, the Road Traffic Safety Agency of the Republic of Serbia states that in traffic accidents which involved tractors and other farm vehicles in the 2011-2015 period, 267 persons were killed, while 2,318 persons sustained grave and light injuries, which was also revealed by electronic media (Agromedia, 2018).

\section{The research method}

The research methods used in the paper are methods of analysis, synthesis, concretization, abstraction, inductive and deductive concluding. The data presented in the paper are summarized and compared, using several different criteria. There is data comparison by region, both individually and regionally. According to six municipalities in western Serbia and in northern Serbia were selected for comparative analysis due to their specific natures and characteristics. Both regions have a large urban area, one region has crop production, and the other fruit and cattle production, as the configuration of the terrain is different. The population of both regions is fairly accurate All the above mentioned creates a relevant basis for analysis, hypothesis testing and drawing conclusions.

The Commission of the Faculty of Traffic Engineering in Belgrade has implemented the Transport Safety Strategy of the City of Valjevo for the 2016-202period (Off. Gazette of the city of Valjevo, 2017), which shows that there is no generally accepted methodology in Serbia for calculating the total socio-economic costs of traffic accidents. The methodologies applied in other countries are significantly different. Depending on the assessment model, the total socio-economic costs per affected person range from the following: 266,358 (Republika Srpska, 2012) to 3,652,265 €/CAS (New Zealand, 2014), or from 10,623 to 664,098 €/SIP and from 354 to 64,208 €/LIP. Bearing in mind the data from the mentioned strategy as well as data related to the time period that was the subject of the analysis for developing the Strategy in correlation with the data on the number of traffic accidents in Valjevo in the 2010-2015 period and the number of persons killed - 3,040 traffic accidents in which 1,521 persons were reportedly killed (killed or injured), there are two variants related to the total social and economic costs per victim. The total socio-economic costs for the victims in this six-year period were estimated from EUR 14.3 million (according to the methodology from Republika Srpska - Traffic Accident Costs in the Republika Srpska, Economic Institute, Banja Luka, 2012) to EUR 435 million (according to methodology from New Zealand), or as follows:

- The costs for 39 casualties were from EUR 10.4 million to 142.4 million.

- The costs for 329 seriously injured persons (SIP) were from EUR 3.5 million to 218.5 million, and 
- The costs for 1,153 persons with light injuries (LIP) were from EUR 408,000 to 74 million.

Bearing in mind the indicators that could objectively refer to the Republic of Serbia, in our opinion, the data relating to the Republic of Srpska in relation to the other data referring to New Zealand are more acceptable. This means that in the further analysis for the reference value of economic costs, one casualty will be given the value of EUR 266,000 (10,400,000/39), and a person with serious bodily injuries EUR 10,600 $(3,500,000 / 329)$.

The following hypotheses are tested in the paper:

The negative effects of traffic accidents which involve farm vehicles are manifested in multiple ways: loss of life, injury, economic damage of a farm vehicle, to negative economic effects on the farmstead due to the absence of a household member as a result of injury and through the costs of terminating the additional commercial activities of the farmstead.

By a comparative analysis of traffic accidents over a period of six years of the six municipalities of western and northern Serbia, the conclusion can be drawn that the number of tractor-related accidents is lower in the plains, which implies a less negative economic impact on the economy of farmsteads in these areas. The reasons are multiple, from the age structure of the tractor, the configuration of the terrain, the average age of the person driving the vehicle, etc.

The financial sector, primarily the insurance sector but also the relevant state institutions, should, through systemic solutions, give greater importance to the elimination of the negative traffic accident-related economic effects which involve farm vehicles, especially if they are driven by heads of farmsteads or family members who are engaged in work, with specific models of assistance to the families of those killed or injured in the period of economic recovery, which is often reduced to mere survival.

\section{Data}

According to the data of the Road Traffic Safety Agency of the Republic of Serbia in 2016, there were 35,971 traffic accidents, of which 14,401 had casualties with 607 people killed and 20,641 persons injured, out of which 3,363 persons received serious bodily injuries, and 17,278 light injuries. In the year 2016, 40 drivers and passengers were killed while driving tractors, and a total of 195 persons were injured by tractors: 80 seriously and 115 lightly. The following table summarizes the data for the 20122016 period. The columns contain data for six municipalities in western and northern Serbia. Data on the total number of traffic accidents, the total number of persons injured and killed on tractors, as well as the number of tractors, farms, number of spouses of household heads, number of other family members, as well as the number of farmsteads that carry out other commercial activities was given, so that there is a comparison of municipalities as well as regions. The data on the farmsteads were taken from the 2012 Agricultural Census of Agriculture. 
Table 1. A comparative presentation of traffic accidents and farmsteads-the municipalities of western and northern Serbia 2012-2016.

\begin{tabular}{|c|c|c|c|c|c|c|c|c|c|c|c|c|}
\hline & 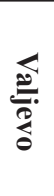 & 过. & $\subseteq$ & 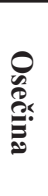 & : & 들: & 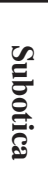 & $\stackrel{\mathscr{D}}{\Xi}$ & 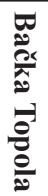 & 胥: & 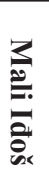 & $\frac{1}{2}$ \\
\hline $\begin{array}{l}\text { Total no. of traffic accidents } \\
\text { with injured and casualties }\end{array}$ & 总 & $\underset{N}{\infty}$ & $\widetilde{J}_{0}^{w}$ & $\checkmark$ & $\vec{\infty}$ & $\vec{\sigma}$ & $\overrightarrow{0}$ & $\varpi_{\infty}$ & $\vec{v}$ & $\bar{u}$ & 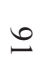 & $\underset{N}{\sim}$ \\
\hline Total no. of persons injured & $\vec{\nabla}$ & నิ & $\underset{\omega}{w}$ & 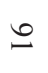 & $\stackrel{N}{a}$ & $\vec{\circ}$ & 苑 & $\stackrel{N}{\omega}$ & $\underset{0}{\tilde{O}}$ & $\stackrel{N}{N}$ & $\vec{D}$ & $\vec{\Im}$ \\
\hline $\begin{array}{l}\text { Number of persons injured on } \\
\text { tractors }\end{array}$ & $\sqrt{ }$ & $\cong$ & $\omega_{\infty}$ & $\Delta$ & N & $\checkmark$ & $\stackrel{N}{A}$ & $\perp$ & $\cong$ & $\overline{0}$ & - & $\Xi$ \\
\hline Total number of casualties & 点 & $\bar{\omega}$ & $\varpi$ & $a$ & $\vec{\perp}$ & $\bar{N}$ & w & 6 & $\varpi$ & $\sigma$ & $\triangle$ & $\checkmark$ \\
\hline $\begin{array}{l}\text { Total number of casualties on } \\
\text { tractors }\end{array}$ & $A$ & 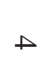 & 0 & $\omega$ & $A$ & $\omega$ & 0 & - & - & 0 & 0 & - \\
\hline Total number of tractors & $\underset{w}{\tilde{w}}$ & 灾 & $\underset{\mathrm{N}}{\stackrel{N}{N}}$ & $\begin{array}{l}\infty \\
+\end{array}$ & $\begin{array}{l}\stackrel{N}{\Delta} \\
\stackrel{\omega}{\omega}\end{array}$ & $\stackrel{N}{\varrho}$ & $\begin{array}{l}\overrightarrow{0} \\
\stackrel{+}{4}\end{array}$ & $\stackrel{\vec{a}}{y}$ & $\underset{\mathcal{S}}{\sim}$ & 崩 & $\sqsupseteq$ & $\underset{\substack{N \\
N}}{\mathbb{N}}$ \\
\hline Number of family farmsteads & 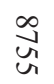 & $\stackrel{\tilde{U}}{0}$ & $\underset{\substack{0 \\
y}}{u}$ & $\underset{\infty}{\sim}$ & $\underset{⿱ 亡}{\stackrel{\omega}{N}}$ & $\ddot{o}_{0}^{0}$ & 离 & $\vec{\exists}$ & $\underset{\infty}{\omega}$ & $\begin{array}{l}N \\
\infty \\
\omega \\
\omega\end{array}$ & $\vec{\omega}$ & g) \\
\hline $\begin{array}{l}\text { Spouses of farmstead heads } \\
\text { (female) }\end{array}$ & $\stackrel{+}{ \pm}$ & $\overrightarrow{\mathrm{H}}$ & 岕 & Na & $\underset{\infty}{\infty}$ & $\overrightarrow{\text { స్ర }}$ & No & $\vec{\sigma}$ & $\underset{\tilde{N}}{\tilde{N}}$ & $\underbrace{w}_{\sigma}$ & $\stackrel{U}{\Delta}$ & $\underset{\omega}{\vec{\omega}}$ \\
\hline $\begin{array}{l}\text { Number of family members } \\
\text { and relatives of farmstead } \\
\text { heads }\end{array}$ & ठ̆ & $\begin{array}{l}\overrightarrow{0} \\
\stackrel{\circ}{a}\end{array}$ & $\stackrel{u}{a}$ & $\begin{array}{l}\vec{w}^{\prime} \\
\ddot{o}\end{array}$ & $\begin{array}{l}\infty \\
+ \\
0\end{array}$ & $\stackrel{N}{ \pm}$ & $\underset{\omega}{\omega}$ & N & $\underset{N}{\tilde{N}}$ & $\underset{\infty}{\sim}$ & $\stackrel{u}{v}$ & $\stackrel{u}{ \pm}$ \\
\hline $\begin{array}{l}\text { Farmsteads carrying out other } \\
\text { commercial activities }\end{array}$ & $\underset{N}{N}$ & $\bar{w}$ & 忍 & స్ & $\stackrel{\infty}{\stackrel{0}{b}}$ & $\begin{array}{l}\infty \\
\stackrel{+}{N}\end{array}$ & 点 & 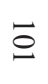 & $\Xi$ & 范 & $\infty$ & 오 \\
\hline
\end{tabular}

Source: Road Traffic Safety Agency, RS, and NSSO (2012-2016).

If we compare the mentioned municipalities, we can notice that the greatest number of traffic accidents with casualties is on the territory of Subotica. If the number of injured persons is analyzed, Subotica and Valjevo had the largest number in the mentioned period, which is understandable considering the number of inhabitants.

Regarding the data collected for the municipalities of western and northern Serbia, we can note that the number of injured persons driving tractors in the 2012-2016 period in western Serbia is 55\% higher, while the number of casualties is 6 times higher than in northern Serbia. 
The total number of family farmsteads in the municipalities of western Serbia is 27,461 , while for it is 17,449 in the northern Serbian municipalities, and when these data are compared with the total number of tractors in the six mentioned municipalities, we can draw the conclusion that there are 1.57 tractors for every one farmstead in western Serbia, and for the municipalities of northern Serbia - 1.26 tractors. We can conclude that according to the number of tractors per family farmstead, western Serbian municipalities are in the lead, which can have an impact on the number of persons injured in tractor-related accidents in comparison with the municipalities of northern Serbia, but also with the Serbian average.

In order to better understand all the economic aspects of tractor-related accidents, data on the number of female spouses as well as data on other family members on farmsteads in the municipalities listed in the previous table was analyzed. The total number of these persons for the municipalities of western Serbia was 38,011, and for the municipalities of northern Serbia - 14,879. When the data are compared with the number of family farmsteads, we can draw the conclusion that for every farmstead, there are 1.38 persons from the category of spouses of the household heads or other family members in the municipalities of western Serbia, while that number is 1.17 persons for northern Serbia. The conclusion is that municipalities in western Serbia have farmsteads and larger families. If we assume that the persons injured and killed in tractor-related accidents are working household members and often, the farmstead heads, the previous data shows that in the case of accidents in the municipalities of western Serbia, a greater number of persons living on family farmsteads can be considered vulnerable, as they are left to manage the farms.

Figure 1. Graphic representation of the number of spouses of household heads and number of family members.

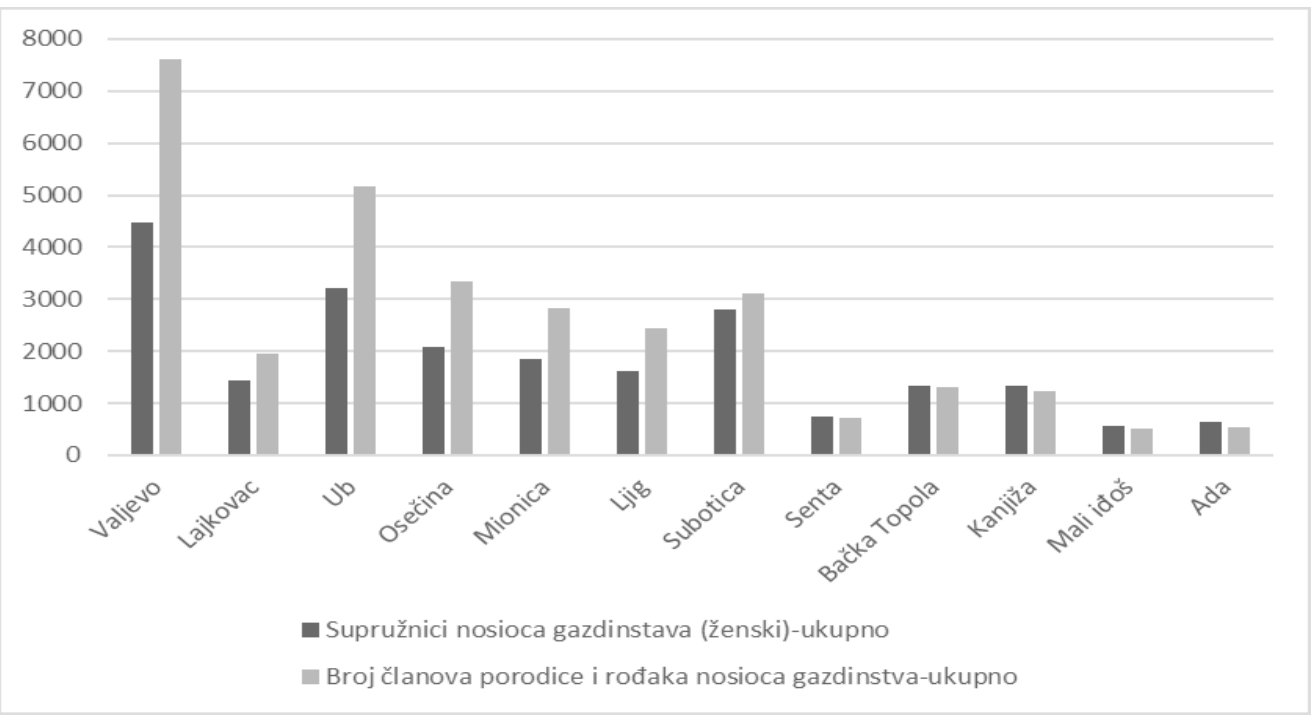

Source: SORS-2012 Agricultural census 
Particularly interesting is the data on the number of farmsteads that carry out other commercial activities, besides the basic one. There are 5.337 or $19.4 \%$ of such farms from the total number of farmsteads in western Serbia, and in the north only 1.114 or $6.3 \%$. This points to the conclusion that family farmsteads in the mentioned northern municipalities are more focused on basic agricultural activities. The somewhat higher "enterprising spirit" of family farmsteads in western Serbia, manifested by a number of additional activities, can be additionally put at risk by the above-mentioned number of traffic-related accidents in this area. It is difficult to make a precise assessment of the negative economic effects on these additional activities, but they without doubt imply an disruption of activity, the inability to meet financial obligations and, of course, a lack of profit.

\section{Discussion of results}

The following table shows the data related to the indicators in the first table, that is, the percentage of persons injured and killed in tractor-related accidents in relation to the total number of persons, the indicator of the age of the tractor, and the percentage of farmsteads that carry out other activities, according to municipalities.

Table 2. Results of comparison - western and northern Serbia municipalities.

\begin{tabular}{|c|c|c|c|c|c|c|c|c|c|c|c|c|}
\hline $2012 / 2016$ & 苛. & 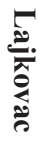 & $\subsetneq$ & 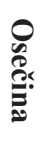 & 递. & 들: & 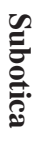 & $\stackrel{\mathscr{0}}{\Xi}$ & 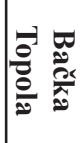 & 页: & 文. & $\frac{1}{2}$ \\
\hline $\begin{array}{l}\% \text { of injured in tractor- } \\
\text { related accidents compared } \\
\text { with the total number of } \\
\text { injured }\end{array}$ & $N$ & $\infty$ & $\checkmark$ & $\omega$ & $\infty$ & 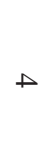 & $N$ & $N$ & $\checkmark$ & 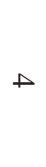 & - & $\checkmark$ \\
\hline $\begin{array}{l}\% \text { of casualties on tractor- } \\
\text { related accidents compared } \\
\text { with the total number }\end{array}$ & 0 & $\omega$ & 0 & Uूo & $\tilde{V}$ & $\stackrel{\sim}{u}$ & 0 & ニ & $u$ & 0 & 0 & $\vec{A}$ \\
\hline $\begin{array}{c}\% \text { of tractors older than } 10 \\
\text { years }\end{array}$ & $\stackrel{2}{\circ}$ & $\stackrel{\circ}{\stackrel{2}{*}}$ & $\begin{array}{l}\text { o } \\
\text { in }\end{array}$ & $\stackrel{0}{u}$ & $\begin{array}{l}0 \\
u i \\
\text { in }\end{array}$ & $\stackrel{2}{2}$ & $\stackrel{\infty}{\infty}$ & $\stackrel{8}{i}$ & $\infty$ & 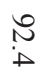 & $\stackrel{\infty}{\rightarrow}$ & $\begin{array}{l}\infty \\
\infty \\
6\end{array}$ \\
\hline $\begin{array}{c}\% \text { farmsteads where other } \\
\text { commercial activities are } \\
\text { carried out }\end{array}$ & $\underset{\omega}{\omega}$ & $\stackrel{\vartheta}{ }$ & $\omega$ & 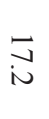 & $\stackrel{N}{\oplus}$ & $\underset{N}{N}$ & $\stackrel{\infty}{\infty}$ & $\ddot{v}$ & $\because$ & $i$ & $\hat{i}$ & $\stackrel{\vartheta}{ }$ \\
\hline
\end{tabular}

Source: SORS-Agricultural census, 2012.

The percentage of injured persons on tractor-related accidents in relation to the total number of injured persons is the highest in Lajkovac and Mionica - 8\%, followed by the municipalities of Ada and Bačka Topola - 7\%, and the fewest in the municipality of Mali Iđoš - 1\%. According to the Road Traffic Safety Agency in 2016, the percentage 
of injured persons on tractor-related accidents (195) in relation to the total number of casualties $(20,641)$ in the Republic of Serbia is $0.94 \%$. According to this indicator, all the listed municipalities are far above the national average, which is also explained by the fact that the number of injured persons is augmented by injuries from urban areas, where there are much fewer farm vehicle accidents than in the analyzed municipalities.

As regards the percentage of casualties in tractor-related accidents compared to the total number of casualties, the Osečina municipality, where half of the casualties were involved in tractor-related accidents, was on the top of the list, followed by the Lajkovac municipality with 31\%, Mionica 29\%, and Ljig 25\%. Of the analyzed municipalities in northern Serbia, a slightly higher percentage of casualties in tractor-related accidents in comparison to the total number of casualties occurred in the municipality of Ada - 14\%. According to the Road Traffic Safety Agency 2016 data, the percentage of casualties in tractor-related accidents compared to the total number of casualties in the Republic of Serbia was $6.59 \%$. The conclusion is that apart from Ub, all the analyzed municipalities of Western Serbia significantly exceeded the national average. In the north, this is valid for the municipalities of Senta and Ada. The preliminary analysis is shown in the graph below.

Figure 2. Graphical representation of the percentage of casualties on tractor-related accidents compared to the total number.

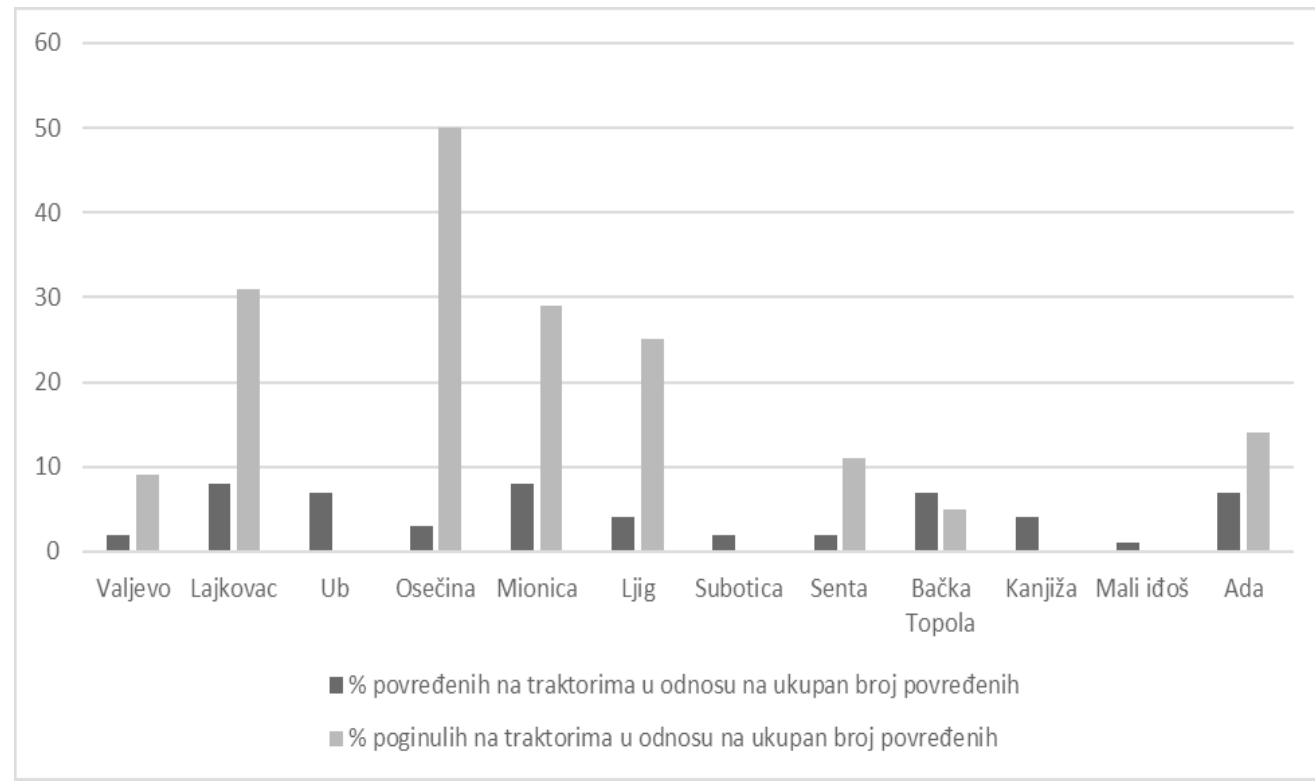

Source: Road Traffic Safety Agency 2012-2016.

The age group of the casualties according to the Road Traffic Safety Agency in the analyzed period in the municipalities of western Serbia is over 46 years old, while for northern Serbia, the average age ranges from 15 to 46, except for Senta and Bačka Topola where the casualties were mostly in the 46-64 age group. 
The quality of farm vehicles and their reliability is defined by their age in Serbia. Although the market for farm vehicles in the first nine months of 2017 recorded a sales growth of around 50\% compared to 2016, with the greatest increase in the tractor market, despite the purchase of new technology, the average age of tractors continues to be 25 years (www.poljoprirednik.net, 2018).

Regarding the areas of western and northern Serbia, which are the subject of this research, we have established that the percentage of tractors older than 10 years is the highest in Valjevo and the Lajkovac region, close to 97\%, while in the Subotica area, as well as in the municipalities of Ada and Mali Iđoš, this percentage is somewhat lower, about $89 \%$ of the total number of tractors. Thus, the analyzed municipalities of western Serbia have farmsteads with only $4 \%$ of tractors under the age of 10 , while in the north this number is about $10 \%$. The use of such old mechanization in the hilly regions certainly increases the risk of traffic accidents, but also explains the actual economic power of the average farmstead.

The percentage of farmsteads carrying out other commercial activities is the highest in the municipalities of Ljig and Mionica, and the lowest is in the municipalities of Senta and Bačka Topola. The conclusion is that the farmsteads in the analyzed municipalities of western Serbia are somewhat more enterprising compared to the north, while the analyzed municipalities in the north have a smaller percentage of older (and thus, more risky) tractors. Below is a graphical presentation.

Figure 3.Graphical representation of the percentage of tractors older than 10 years and farmsteads which carry out other commercial activities 2012-2016.

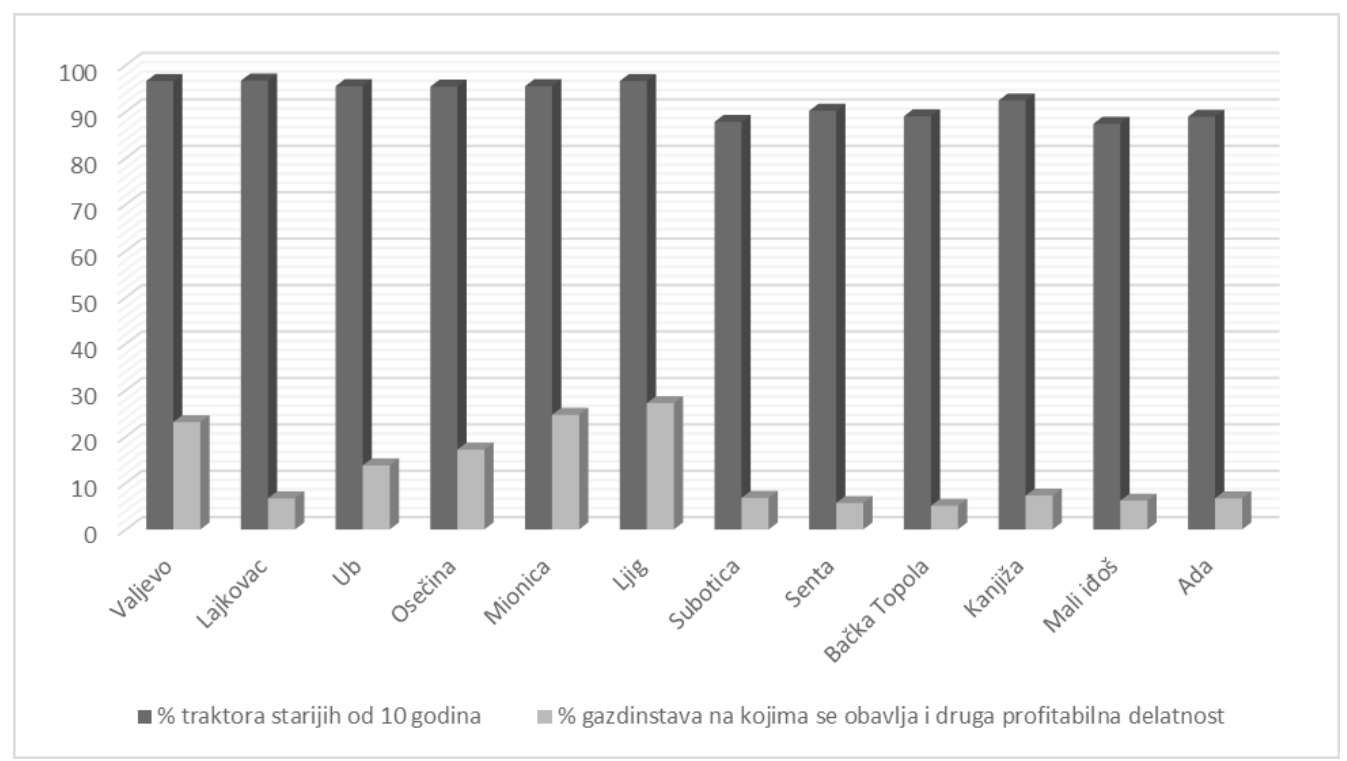

Source: Road Traffic Safety Agency 2012-2016. 
In the calculation of the economic effects of tractor-related traffic accidents in the mentioned municipalities, we will use data on costs for road traffic victims, which we analyzed in the first part of this paper, which are EUR 266,000 per victim, i.e. EUR 10,600 per person with physical injuries. We can conclude that in the observed period, in the municipalities of western Serbia, 18 people died in tractor-related accidents, which corresponds to an "economic cost" of EUR 4,788,000, while for northern municipalities, this amount was EUR 798,000 for the same period. Given the fact that there is no data if all of them were household heads but assuming they were (or a majority of them), opportunity costs should be included in the calculation of the negative economic effects, which actually indicates a loss of profit due to a standstill or a reduced volume of farm business caused by traffic accidents. The opportunity cost differs according to farmstead, production volumes, whether the person involved was the only worker on the farmstead, if the tractor was used actively on the farmstead, etc. If these data were available, a more detailed economic analysis and calculation of summarized economic effects could be made, but due to lack of data, we fall short of expectations.

\section{Conclusion and recommendations}

Based on the preliminary analysis, we can conclude that tractor-related traffic accidents have multiple adverse effects, which are manifested not only in the loss of human lives and injuries, but also a series of negative economic effects pertaining to farmsteads and their members who participated in the accidents.

A comparative analysis of the data leads to the conclusion that the negative economic effects of these accidents in the 2012-2016 period were higher on the territory of the six analyzed municipalities of western Serbia, compared to the municipalities of northern Serbia according to the criteria of the number of casualties, but also the damages criteria, and the opportunity costs incurred by loss of profit due to a standstill or decrease of commercial activities. The above conclusions essentially confirm the first hypothesis of this paper, as well as other hypotheses.

The average age of the vehicle, the age of the drivers, the number of tractors, and the configuration of the terrain increase the risks of traffic accidents and the mentioned negative effects, which are somewhat lower in the municipalities of northern Serbia compared to the municipalities of western Serbia.

It is recommended that the financial sector, first and foremost the insurance sector, is to actively engage in solving this problem through systematic solutions to support the farmstead families of the victims, with the support of the competent state institutions. The fact is that there is insufficient focus on the negative economic effects caused by farm vehicle-related traffic accidents, primarily tractors, especially if they were driven by household heads or working family members. The damage, as the paper proves, is calculated in millions of Euros only in the two analyzed regions, while the figure in the territory of the Republic of Serbia is much higher.

In fact, there are no systematic, concrete models for helping the families of the casualties and those injured during the period of economic recovery. The availability of insurance 
policies, better information, and wider support in difficult periods for farmsteads can be crucial for overcoming such problems, which, often due to all the negative effects mentioned, are reduced to the perils of existence and unrelenting survival.

\section{Conflict of interests}

The authors declare no conflict of interest.

\section{References}

1. Agricultural Census (2012). Republic Institute of Statistics of the Republic of Serbia [in Serbian: Popis poljoprivrede (2012). Republički zavod za statistiku Republike Srbije].

2. Agromedia, 2018, https:/www.agromedia.rs/agro-teme/mehanizacija/ traktoristi-povedite-vise-račununa-o-bezbednosti-u-saobracaju, 24.06.2017, retrieved on March 1, 2018.

3. Ayers, P., Khorsandi, F., Wang, X., Araujo, G. (2018). ROPS designs to protect operators during agricultural tractor rollovers. Journal of Terramechanics. (75) 49-55. https://doi.org/10.1016/j.jterra.2017.05.003

4. Blower D., Campbell KL., Green PE.(1993). Accident rates for heavy trucktractors in Michigan, Accident Analysis \& Prevention, (25) 3, Elsevier, 307-21.

5. Centers for Disease Control, (2003). Rasmussen RC, Schermann MA, Shutske JM, Olson DK., Use of North American guidelines for children's agricultural tasks with Hmong farm families, J Agric Saf Health, 9 (4),265-74.

6. Communication from the Commission "Keep Europe moving - Sustainable mobility for our continent, Mid-term review of the European Commission's 2001 Transport" - White Paper (2006); Communication from the Commission, "European road safety action programme - Halving the number of road accident victims in the European Union by 2010: a shared responsibility," (2003); Promoting Road Safety in the EU, the program for 1997-2001, Commission of the European Communities, Brussels, 1997; United Nations, General Assembly, Resolution 60/5. "Improving global road safety," Geneva, (2005); White Paper, "European Transport Policy for 2010, Time to Decide," European Commission, 2001.

7. Conference on Improving Road Safety in the BSEC Region, 18-19 November 2010, Ioaninna, Greece, available at: http://www.unece.org/trans/roadsafe/conf ioaninna.html (November 18-19, 2010)

8. Criminal Code, Off. Gazette of the Republic of Serbia, nos. 85/2005, 88/2005, 107/2005, 72/2009,111/2009, 121/2012, 104/2013, 108/2014, 94/16 [in Serbian: Krivični zakonik Republike Srbije, Službeni glasnik Republike Srbije br. 85/2005, 88/2005, 107/2005, 72/2009,111/2009, 121/2012, 104/2013, $108 / 2014,94 / 16]$. 
9. European Charter on Traffic Safety, signed by the Auto Moto Association of Serbia 25.8.2009. [in Serbian: Evropska povelja o bezbednosti saobraćaja koju je potpisao Auto moto savez Srbije 25.8.2009.godine]. Retrieved 2018, from http://www.amss.rs

10. Grewe,G.,(2005). Strassenverkehrsdelinquenz und Marginalität, Untersuchen zur Institutionen Regelung von Verhalten, Peter Lang, Frankruft am Main/ Bern/ Las Vegas.

11. Hoy, R.M., (2009). Farm tractor rollover protection: why simply getting rollover protective structures installed on all tractors is not sufficient. J. Agric. Safety Health, 15(1), 3-4.

12. Lee, B., Marlenga, B. (1999). Professional Resources Manual: North American Guidelines for Children's Agricultural Tasks, Marshfield, WI.: Marshfield Clinic.

13. Liu, B., Koc, A.B., (2013). SafeDriving: a mobile application for tractor rollover detection and emergency reporting. Comput. Electron. Agric., (98), 117-120. Doi 10.1016/j.compag.2013.08.002

14. Marlenga, B., Berg, R.L., Pickett, W., Brown,T., Becklinger, H., Schwebel, D.C., (2017). Using simulation to assess the ability of youth to safely operate tractors. Transportation Research, (48), 28-37. https://doi.org/10.1016/j. trf.2017.04.021

15. Marković, N., Ivanišević, T., Petrović, T., Vukšić, V. (2013). Analysis of the causes of traffic accidents with the participation of the tractors. $2^{\text {nd }}$ Expert seminar Safety in the local community, Banja Luka. [in Serbian: Марковић, Н., Иванишевић, Т., Петровић, Т., Вукшић, В. (2013). Анализа узрока настанка саобраћајних незгода са учешћем трактора. 2. стручни семинар Безбједност саобраћаја у локалној заједници, Бања Лука]. Retrieved 2018, from https://www.absrs.org/sajt/doc/File/23_\%20Markovic\%20N\%20 Ivanisevic\%20T\%20Petrovic\%20T\%20Vuksic\%20V\%20_Analiza.pdf

16. Martin-Gorriz, B., Ibarra Berrocal, I., Mínguez Samper, A., Morente Sánchez, A., (2012). Accidentes por vuelco de tractor de la Región de Murcia: propuestas para su reducción. Form. Segur. Lab. (123), 70-71 (in Spanish).

17. Methodology from the Republic of Srpska (2012).Economic Institute, Banja Luka, Cost of traffic accidents in the Republic of Srpska. [in Serbian: Metodologija iz Republike Srpske (2012). Ekonomski institut, Banja Luka, Troškovi saobraćajnih nezgoda u Republici Srpskoj].

18. Methodology from New Zealand (2014). [in Serbian: Metodologija iz Novog Zelanda(2014)].(http://www.transport.govt.nz/assets/Uploads/Research/ Documents/Social-Cost-of-Road-Crashes-and-Injuries-June-2014-update.pdf (October 21, 2016).

19. NORA AgFF Sector Council, (2008). National Occupational Research Agenda (NORA) Agriculture, Forestry, and Fishing (AgFF) Sector Council - National Agriculture, Forestry, and Fishing Agenda. 
20. OECD (2006). Policy brief October 200, "Young drivers: The road to safety". http:www.internationaltransportforum.org/jtrc/safety/YDpolicyBrief.pdf (January 20, 2008)

21. Off. Gazette of the City of Valjevo, (2017). no. 5 Volume 2, p.48.[in Serbian: Službeni glasnik Grada Valjeva, (2017). br. 5 sveska 2, str.48].

22. Poljoprivrednik, http://www.poljoprivrednik.net/agriculture/ products-industry/2897-operative-investment-agricultural-technicians 22 December 2017, retrieved on March 1, 2018

23. Pešić, D., Antić, B., Pešić, D., Vujanić, M.M. (2010). Creation of hazards by agricultural machines in night conditions, IX Symposium "Dangerous situation and credibility of the occurrence of a traffic accident (insurance fraud)," Zlatibor, 27-48 [in Serbian: Pešić, D., Antić, B., Pešić, D., Vujanić, M.M. (2010). Stvaranje opasnosti od strane poljoprivrednih mašina u noćnim uslovima. IX Simpozijum „, Opasna situacija $i$ verodostojnost nastanka saobraćajne nezgode (prevare u osiguranju),"Zlatibor, 27-48].

24. Road Traffic Safety Agency, Statistical report on the state of traffic safety in the Republic of Serbia in 2016. [in Serbian: Agencija za bezbednost saobraćaja, Statistički izveštaj o stanju bezbednosti saobraćaja u Republici Srbiji u 2016. godini].

25. Schwebel \& Pickett, (2012). The role of child and adolescent development in the occurrence of agricultural injuries: an illustration using tractor-related injuries, Journal of Agromedicine, 17(2), 214-224. DOI:10.1080/105992 4X.2012.655120

26. World Health Organisation (WHO) (2004). World report on road traffic injury prevention, Geneva. 